\title{
Pengaruh Pupuk Organik Cair Urin Kambing dan Pestisida Alami terhadap Pertumbuhan Tanaman Kacang Panjang Beda Varietas di Desa Gunung Selamat
}

\author{
Sarah Kristi Pertiwi*, Khairul Rizal, Yudi Triyanto \\ Program Studi Agroteknologi, Fakultas Sains dan Teknologi, Universitas Labuhanbatu, Sumatera Utara, Indonesia \\ *Corresponding Author: \\ E-mail: sarahkristisimanjuntak115@gmail.com \\ Received: \\ 1 January 2021 \\ Revised: \\ 15 April 2021 \\ Accepted: \\ 15 May 2021 \\ Published: \\ 31 May 2021
}

\begin{abstract}
Abstrak
Kacang Panjang (Vigna sinensis L.) merupakan salah satu tanaman sayuran sebagai sumber vitamin dan mineral. Kacang panjang (Vigna sinensis L.) juga merupakan jenis kacangkacangan yang banyak diusahakan di Indonesia. Desa Gunung Selamat merupakan salah satu desa dengan penghasilan tanaman palawija yang beragam salah satunya kacang panjang (Vigna sinensis L.). Namun, pengabdian masyarakat ini dilakukan karena banyak permasalahan yang dihadapi oleh petani sehingga menyebabkan pertumbuhan kacang panjang (Vigna sinensis L.) menurun. Turunnya produksi ini antara lain disebabkan oleh iklim, tanah, pupuk, hama dan penyakit. Maka dari itu pengabdian masyarakat ini dilakukan untuk meningkatkan pertumbuhan tanaman serta mengurangi penggunaan pupuk sintetik yang dapat merusak ekosistem tanah, maka dari itu diberi perlakuan penyiraman pupuk organik cair pada tanah serta penyemprotan pestisida nabati dari daun pepaya untuk mencegah hama dan penyakit yang menyerang tanaman kacang panjang (Vigna sinensis L.). Perlakuan ini dibuat untuk melihat hasil respon tingkat pertumbuhan pada tanaman kacang panjang (Vigna sinensis L.).
\end{abstract}

Kata kunci: Kacang Panjang (Vigna sinensis L.); Pupuk Organik Cair; Pestisida Alami.

\begin{abstract}
Abstrack
Long beans (Vigna sinensis L.) are a vegetable plant as a source of vitamins and minerals. Long beans (Vigna sinensis L.) are also a type of legume that is widely cultivated in Indonesia. Gunung Selamat Village is one of the villages with a variety of agricultural crops, one of which is long beans (Vigna sinensis L.). However, this community service was carried out because of the many problems faced by farmers, which caused the growth of long beans (Vigna sinensis L.) to decline. The decline in production was caused, among others, by climate, soil, fertilizers, pests and diseases. Therefore, this community service is carried out to increase plant growth and reduce the use of synthetic fertilizers that can damage the soil ecosystem, therefore it is given the treatment of sprinkling liquid organic fertilizers on the soil and spraying vegetable pesticides from pepaya leaves to prevent pests and diseases that attack long bean plants (Vigna sinensis L.). This treatment was designed to see the results of the growth rate response in long bean plants (Vigna sinensis L.).
\end{abstract}

Keywords: Long Beans (Vigna sinensis L.), Liquid Organic Fertilizer, Natural Pesticides. 


\section{PENDAHULUAN}

Sayuran memegang peranan yang sangat penting dalam memenuhi kebutuhan pangan masyarakat dan peningkatan gizi karena sayuran merupakan salah satu sumber mineral dan vitamin yang dibutuhkan oleh manusia. Sadar bahwa makan sayur akan menyehatkan tubuh, maka konsumsi sayur mulai meningkat saat ini. Kacang panjang merupakan sumber vitamin dan mineral yang penting. Sayuran ini banyak mengandung vitamin A, vitamin B dan vitamin $C$ terutama pada buah polong yang masih muda. Biji kacang panjang banyak mengandung protein, lemak dan karbohidrat. Oleh karena itu kacang panjang dipromosikan sebagai sumber protein nabati, sebagai upaya peningkatan gizi masyarakat murah dan mudah dikembangkan di berbagai daerah. (Oktavianti et al., 2017)

Tanaman kacang panjang (Vigna sinensis L.) merupakan tanaman sayuran kacangkacangan yang banyak ditanam di Indonesia. Kacang panjang ini bukan asli Indonesia, tetapi berasal dari India dan Afrika Tengah yang sudah ada di Indonesia selama ratusan tahun. (Arinong, 2013). Sayur ini banyak mengandung vitamin A, vitamin B, dan vitamin $C$ terutama pada polong yang masih muda. Biji kacang panjang banyak mengandung lemak, protein, dan karbohidrat. Dengan demikian, komoditi ini merupakan sumber protein nabati yang cukup potensial Haryanto (2007).

Berdasarkan Data Departemen Pertanian menyatakan luas panen kacang panjang nasional pada tahun 2005 mencapai 84,839 ton/ha dengan produksi polong segar 466,387 ton/ha, pada tahun 2006 terjadi penurunan luas panen dengan luas panen 84,7988/ha dengan produksi polong 461,239 . Hal ini juga diikuti penurunan produktivitas 5,5 ton/ha pada tahun 20055,4 ton/ha pada tahun 2006 (Zaevie et al., 2014). Berbagai permasalahan yang dihadapi petani kacang panjang menyebabkan penurunan produksi kacang panjang. Penyebab penurunan produksi kacang panjang antara lain iklim, tanah, pemupukan, penyakit dan hama serangga. Salah satu cara untuk meningkatkan produksi kacang panjang adalah dengan memperbaiki teknik pemupukan. Selama ini petani umumnya menggunakan pupuk sintetis.

Hal ini menyebabkan penurunan kandungan bahan organik tanah, mengurangi kapasitas penyangga tanah, dan mendorong pencucian unsur hara di lingkungan akar, sehingga mengurangi penggunaan pupuk. Oleh karena itu, diperlukan pupuk organik sebagai pengganti untuk menggantikan atau mengurangi penggunaan pupuk sintetis. Dalam pengabdian masyarakat ini, kami akan mencoba menggunakan pupuk organik cair dari urine kambing (Selvia Kurdianingsih, 2017).

Tanah yang subur dan gembur diperlukan oleh tanaman kacang panjang. Agar dapat tumbuh dengan baik, tanaman ini menghendaki tanah yang subur, banyak mengandung bahan organik dan cukup mengandung air. Jenis tanah yang paling baik untuk tanaman ini adalah tanah bertekstur liat berpasir. Kacag-kacangan peka terhadap akalin atau kemasaman tanah yang tinggi. Untuk pertumbuhan yang optimal diperlukan derajad keasaman $(\mathrm{pH})$ tanah antara 5,5-6,5 (Haryanto, 2007).

Pupuk berperan penting dalam meningkatkan hasil panen, terutama pada tanah dengan kandungan hara yang rendah. Sedangkan pupuk organik adalah istilah umum untuk komponen dari limbah perikanan atau peternakan. Pupuk organik mengandung unsur hara yang lebih lengkap dibandingkan dengan pupuk kimia (Simanungkir et al., 2006).

Pupuk organik cair mengandung unsur hara dan mikroorganisme yang bermanfaat bagi tanaman. Mikroorganisme ini meliputi: bakteri fotoprotein, bakteri asam laktat, ragi atau ragi, aktinomiset, jamur fermentasi (Aspergillus). Selain memberikan unsur hara bagi tanah, mikroorganisme ini juga sangat penting untuk pencegahan penyakit tanaman (Kurniawan et al., 2017). Manfaat pupuk organik cair antara lain memberikan unsur hara bagi tanaman, memperbaiki struktur tanah, dan menghambat bakteri berbahaya di dalam tanah. Penggunaan pupuk organik cair pada tanah secara terus menerus akan memperbaiki sifat fisik, kimia dan biologi tanah yang aman bagi lingkungan. 
Pupuk organik dapat merangsang dan meningkatkan jumlah mikroorganisme di dalam tanah yang jumlahnya jauh lebih banyak dibandingkan dengan pupuk kimia. Pupuk organik juga dapat memperbaiki struktur dan kesuburan tanah. Tak heran jika pupuk organik dapat mencegah erosi tanah. Pada dasarnya produksi pupuk organik cair juga bertujuan untuk memperkaya unsur hara dalam pupuk. Dalam hal ini, urine kambing atau yang biasa disebut dengan biourea bisa digunakan. Dimungkinkan juga untuk menggunakan kotoran ternak padat (kotoran) atau disebut pertanian hayati (Dudung, 2013).

Penggunaan pupuk kimia dalam jangka panjang akan merusak ekosistem tanah. Penggunaan pupuk kimia juga dapat meningkatkan keasaman tanah yang mengakibatkan kematian banyak mikroorganisme tanah. Berkurangnya mikroorganisme dalam tanah menyebabkan penurunan suplai hara yang dapat diserap tanaman, sehingga tanaman tidak subur dan hasil panen menurun.

Hama merupakan binatang perusak tanaman budidaya yang berguna untuk kesejahteraan manusia. Hama merusak tanaman dengan berbagai cara misalnya memakan daun, melubangi dan membuat korok-korok pada batang, menggerek daun, dan memakan bunga. Adapun beberapa penyebab terjadinya hama pada tanaman antara lain perubahan tempat, perubahan lingkungan, serta aplikasi pestisida kimia yang tidak bijaksana atau terlalu berlebihan (Setiyawan, 2013).

Penyakit merupakan penyebab tanaman menjadi sakit, misalnya bakteri, cendawan, virus, kekurangan atau kelebihan air, kekurangan dan kelebihan unsur hara, serta terlalu panas atau terlalu dingin. Penyakit infeksi pada tanaman dapat disebabkan oleh cendawan ( jamur, fungi ), bakteri, virus, nematode, dan tumbuhan parasit. Gejala yang ditunjukkan oleh penyakit tanaman dapat bermacam-macam, misalnya tanaman kerdil, tumbuh terhambat, busuk akar, busuk batang, busuk daun, busuk buah, busuk umbi, bercak-bercak pada daun, daun menguning (klorosis), jaringan daun mati (nekrosis), timbulnya bisul-bisul, dan sebagainya. Ada beberapa jenis penyakit yang mudah diamati. Namun, umumnya untuk mengidentifikasi penyakit pada tanaman tidak selalu mudah karena gejalanya sering tidak tampak jelas (Djojosumarto, 2008).

Pestisida adalah bahan sintetis yang digunakan untuk mengendalikan berbagai jenis hama. Awalnya manusia menggunakan pestisida nabati untuk membasmi hama, namun semenjak ditemukannya Dichloro diphenyl trichloroethane (DDT) pada tahun 1939, telah memberikan hasil yang cepat dan efektif, sehingga meningkatkan kepercayaan petani terhadap pestisida sintetis yang pada akhirnya menyebabkan ketergantungan pada pestisida berdampak negatif terhadap kesehatan dan bahaya konsumen, karena akan menyebabkan terakumulasinya zat-zat berbahaya di alam, yang pada akhirnya akan mempengaruhi organisme bukan sasaran (Djojosumarto, 2008).

Dalam rangka pengendalian penyakit dan hama serangga yang tidak berbahaya bagi kesehatan konsumen dan tidak berbahaya bagi lingkungan, bahan alam cukup berpotensi menjadi insektisida pada tumbuhan atau insektisida yang biasa disebut dengan insektisida nabati. Pestisida yang terbuat dari bahan nabati sebenarnya bukan barang baru, tetapi sudah digunakan sejak lama. Karena pertanian tradisional masih dipraktikkan, para petani di seluruh dunia telah terbiasa menggunakan bahan-bahan yang tersedia di alam untuk mengendalikan hama tanaman. Pada tahun 1940-an, beberapa petani di Indonesia menggunakan bahan nabati sebagai pestisida, di antaranya menggunakan daun Acanthopanax senticosus untuk mengendalikan belalang dan serangga batang padi. Saat ini beberapa jenis pestisida tanaman sudah mulai digunakan dalam pembudidayaan berbagai tanaman di pertanian organik. Namun demikian, kekuatan atau sifat mematikan masing-masing pestisida terhadap hama tanaman masih perlu dikaji secara mendalam untuk mendapatkan efek pengendalian yang efektif dan efektif (Hodiyah \& Hartini, 2015).

Tanaman pepaya mengandung bahan aktif papain yang efektif mengendalikan ulat dan hama serta pengisap tanaman. Menurut penelitian yang dilakukan (Julaily et al., 2013) getah pepaya mengandung kelompok protease sistein, seperti papain dan kimotripsin. Getah pepaya 
menghasilkan alkaloid, terpenoid, flavonoid, dan asam amino non-protein, yang sangat beracun bagi serangga. Kandungan senyawa dalam tanaman pepaya dapat membunuh hama.

Cara pengendalian yang ramah lingkungan dan cocok untuk diterapkan di area luas seperti di lahan pertanian di Desa Gunung Selamat. Cara pengendalian ramah lingkungan tersebut adalah dengan menggunakan pestisida nabati yang berbahan baku dari tanaman lokalitas namun efektif mengendalikan hama.

Berdasarkan permasalahan-permasalahan yang ada diatas maka perlu diberikan perlakuan pupuk organik cair, serta pestisida alami. Pupuk organik cair dari urine kambing ini merupakan sejenis pupuk cair yang mudah larut dalam tanah dan memiliki unsur penting dalam kesuburan tanah. Pupuk organik cair merupakan salah satu bahan terpenting untuk meningkatkan kesuburan tanah secara aman, dalam arti produk pertanian yang dihasilkan tidak mengandung bahan kimia yang berbahaya bagi kesehatan manusia, sehingga dapat dimakan dengan aman (Elmi Sundari, 2012). Sedangkan, pestisida nabati dari daun pepaya sendiri mampu membantu dalam menanggulangi hama dan penyakit yang meyerang pada tanaman kacang panjang (Vigna sinensis L.).

\section{METODE}

Pengabdian Masyarakat Program Merdeka Belajar Kampus Merdeka ini dilakukan di Dusun Siluang 1, Desa Gunung Selamat, Kecamatan Bilah Hulu, Kabupaten Labuhanbatu, Provinsi Sumatera Utara. Waktu pelaksanaan ini berlangsung selama \pm 3 Bulan, dari tanggal 10 Oktober 2020 - 16 Januari 2021.

Pembuatan metode kegiatan ini menggunakan Rancangan Acak Kelompok (RAK) dengan 2 perlakuan dan 1 ulangan dalam 2 petak bedengan. Ukuran petak bedengan $1 \times 5 \mathrm{~m}$. Faktor yang diamati adalah pertumbuhan tanaman kacang panjang serta hama dan penyakit yang meyerang untuk melihat hasil perbedaan dari pemberian pestisida kimia dan penggunaan pestisida organik.

Alat yang digunakan untuk pembuatan pupuk organik cair dalam penelitian ini yaitu : jerigen, kayu, tong, plastik kaca, dan karet ban, sedangkan alat yang digunakan untuk pembuatan pestisida organik yaitu : ember, pisau, saringan, dan botol semprot.Bahan yang dibutuhan dalam pembuatan pupuk organik cair adalah : urin kambing 60 liter, EM4 1 liter, terasi 1,5 liter, dan gula merah 1,5 liter, sedangkan bahan yang dibutuhkan dalam pembuatan pestisida organik adalah daun pepaya muda \pm 10 helai, bawang putih $1 / 2$ ons, dan air 2 liter.

Perlakuan pertama (J1P1), yaitu dengan pestisida organik yang dimana bahan utama dalam pembuatannya yaitu daun pepaya, dengan mengaplikasikannya di semprotkan ke tamanan kacang panjang setiap 2 kali sehari yaitu pagi dan sore hari dengan dosis $500 \mathrm{ml}$.

Perlakuan kedua (J1P2), yaitu dengan pestisida kimia pengaplikasiannya yaitu dengan cara di semrotkan ke tanaman kacang panjang (Vigna sinensis (L.) setiap 2 kali sehari yaitu pagi dan sore hari dengan dosis yang sama pada pestisida organik $500 \mathrm{ml}$.

Analisis data ntuk mengetahui hasil pertumbuhan dan pengaruh dari aplikasi perlakuan yang telah diberikan, data hasil pengamatan sehingga diperoleh nilai rata-rata, selanjutnya dilakukan analisis ragam sesuai rancangan yang digunakan.।

\section{Teknik Pelaksanaan Kerja}

Teknik pelaksanaan program kerja dalam KKN Tematik ini yaitu sebagai berikut:

1. Rabu, 04 November 2020 


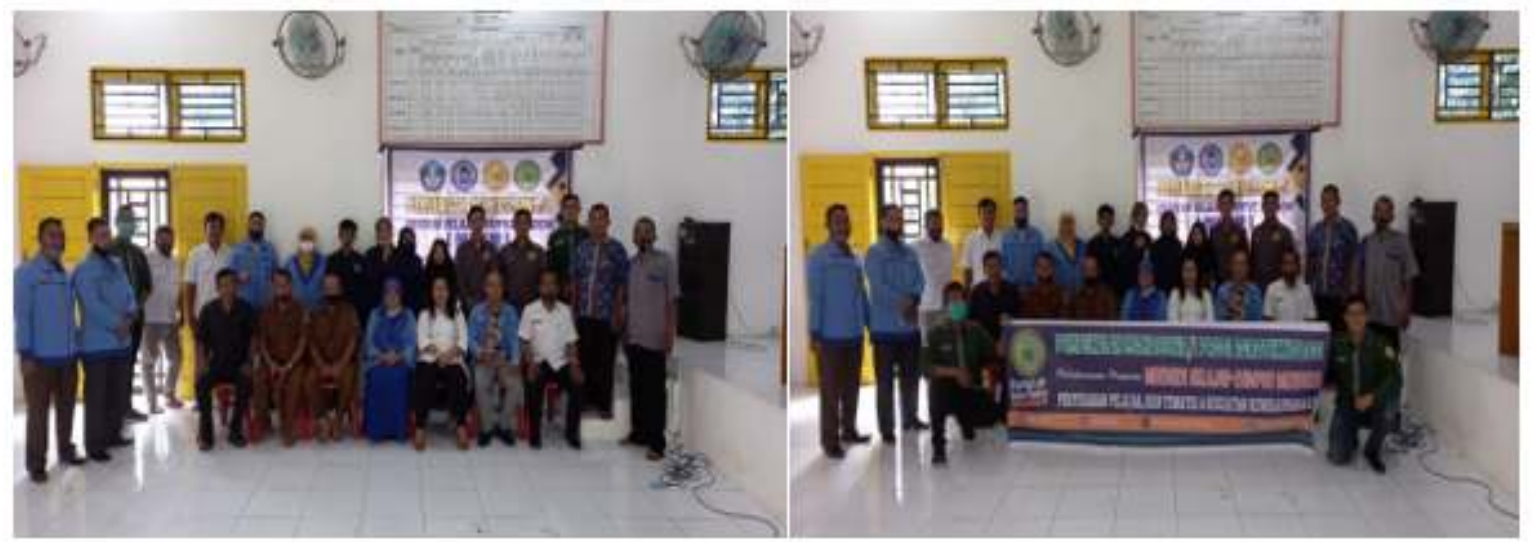

Gambar 1. Pengantaran dan penyerahan mahasiwa/i KKN - Tematik Universitas Labuhan Batu ke Desa Gunung Selamat.

2. Tanggal $10-11$ November 2020

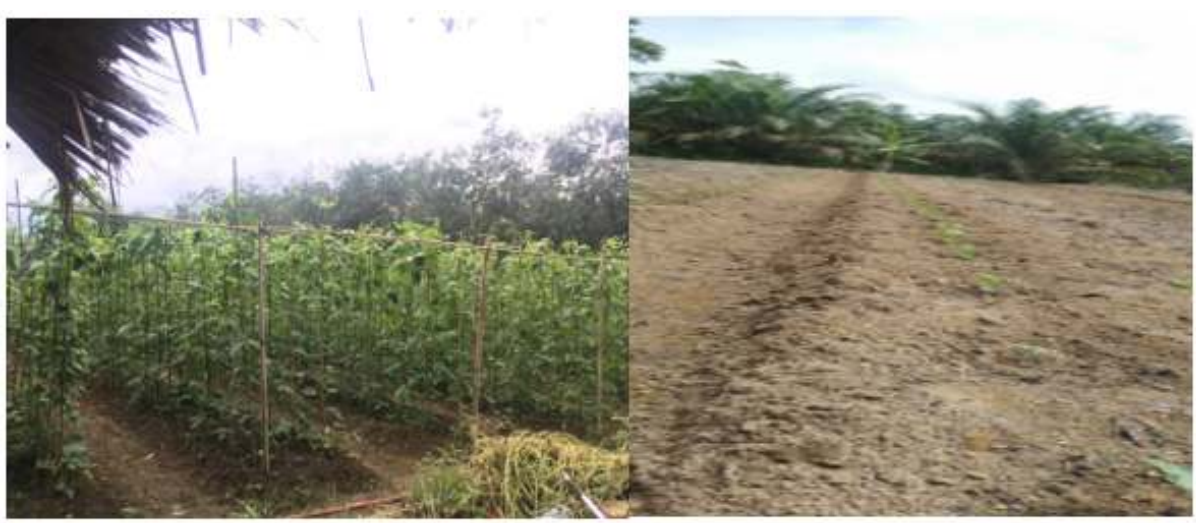

Gambar 2. Observasi lahan di Desa Gunung Selamat.

3. Tanggal $17-18$ November 2020

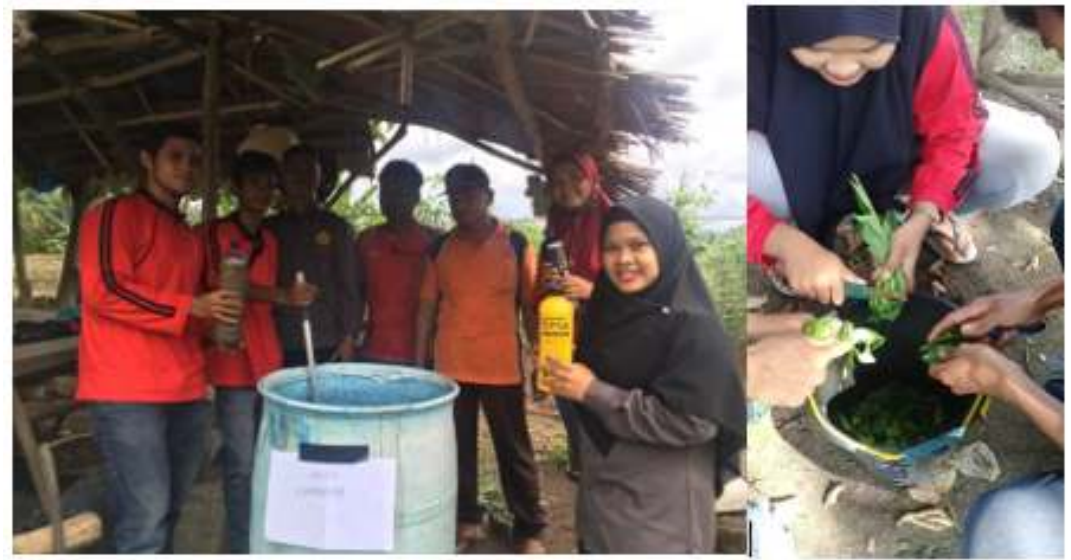

Gambar 3. Pengumpulan alat dan bahan untuk pembuatan Pupuk Organik Cair (POC) urin kambing dan pestisida organik. 
Indonesian Journal of Community Services

Volume 3, No. 1, May 2021

http://jurnal.unissula.ac.id/index.php/ijocs

DOI: http://dx.doi.org/10.30659/ijocs.3.1.19-30

4. Tanggal 24-25 November 2020

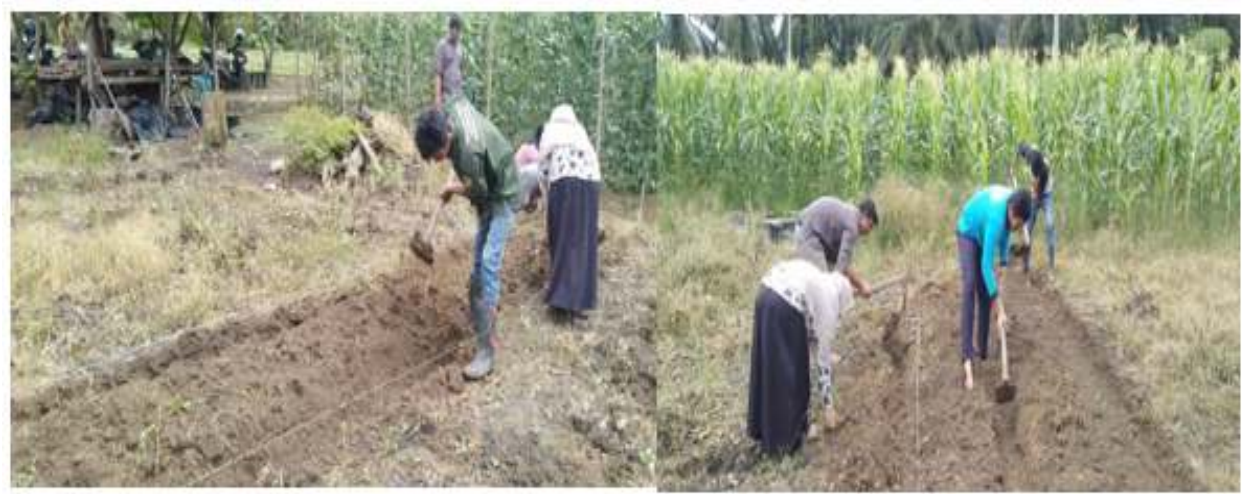

Gambar 4. Pembuatan lahan untuk uji kelayakan pupuk organik cair yang disiramkan ke bedengan.

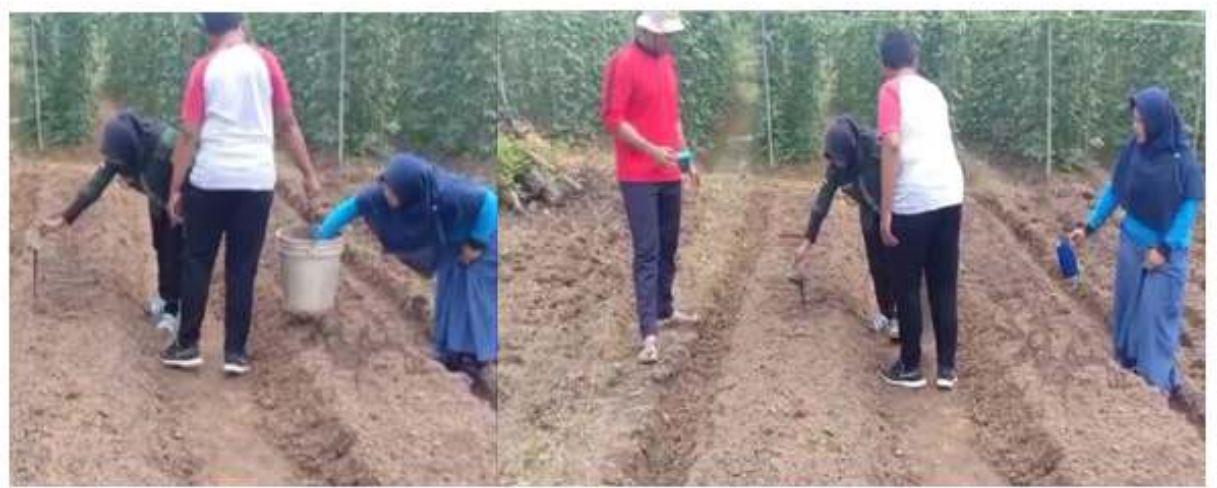

Gambar 4. Penyiraman POC pada lahan.

5. Tanggal 01-02 Desember 2020

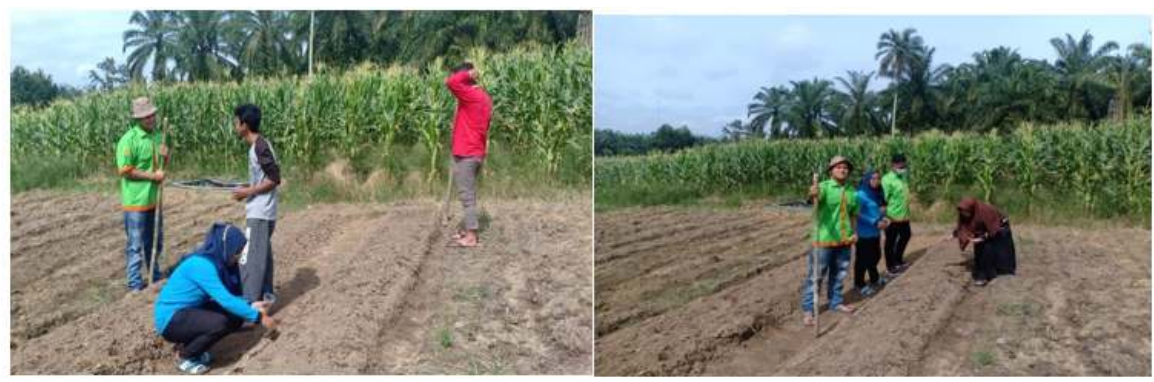

Gambar 5. Penanaman benih kacang panjang pada lahan uji POC dan pencarian batang untuk menopang tanaman kacang panjang. 
Indonesian Journal of Community Services

Volume 3, No. 1, May 2021

http://jurnal.unissula.ac.id/index.php/ijocs

DOI: http://dx.doi.org/10.30659/ijocs.3.1.19-30

6. Tanggal 08-09 Desember 2020

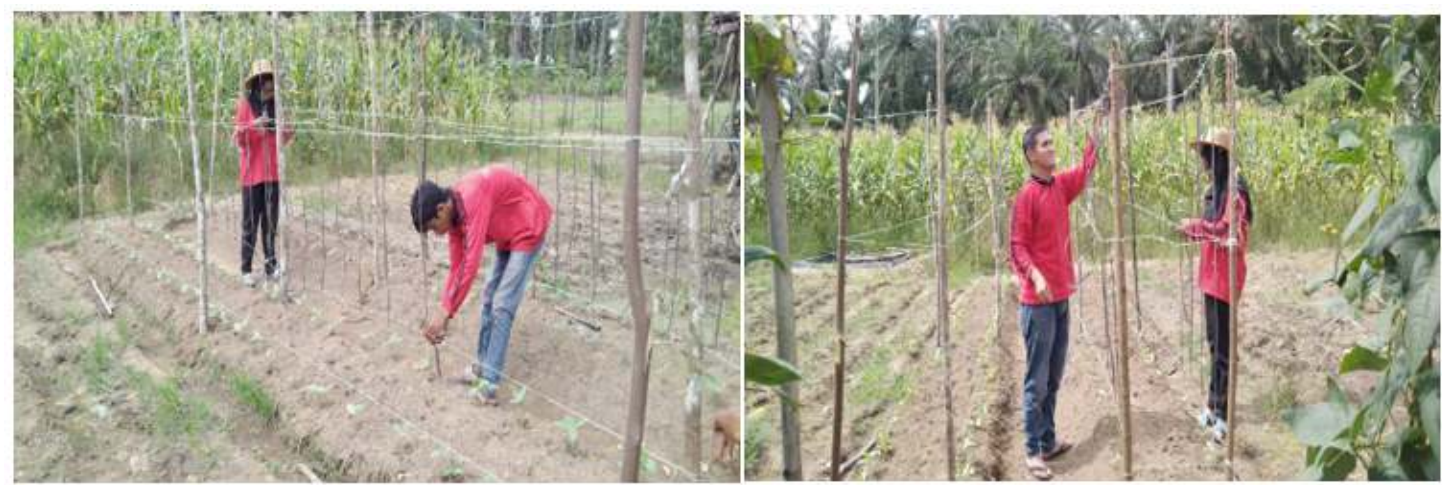

Gambar 6. Pembuatan penyangga untuk penjalaran pada tanaman kacang panjang.

7. Tanggal 08, 15, 16, 22, 23, 29 Desember 2020 - 05 Januari 2021

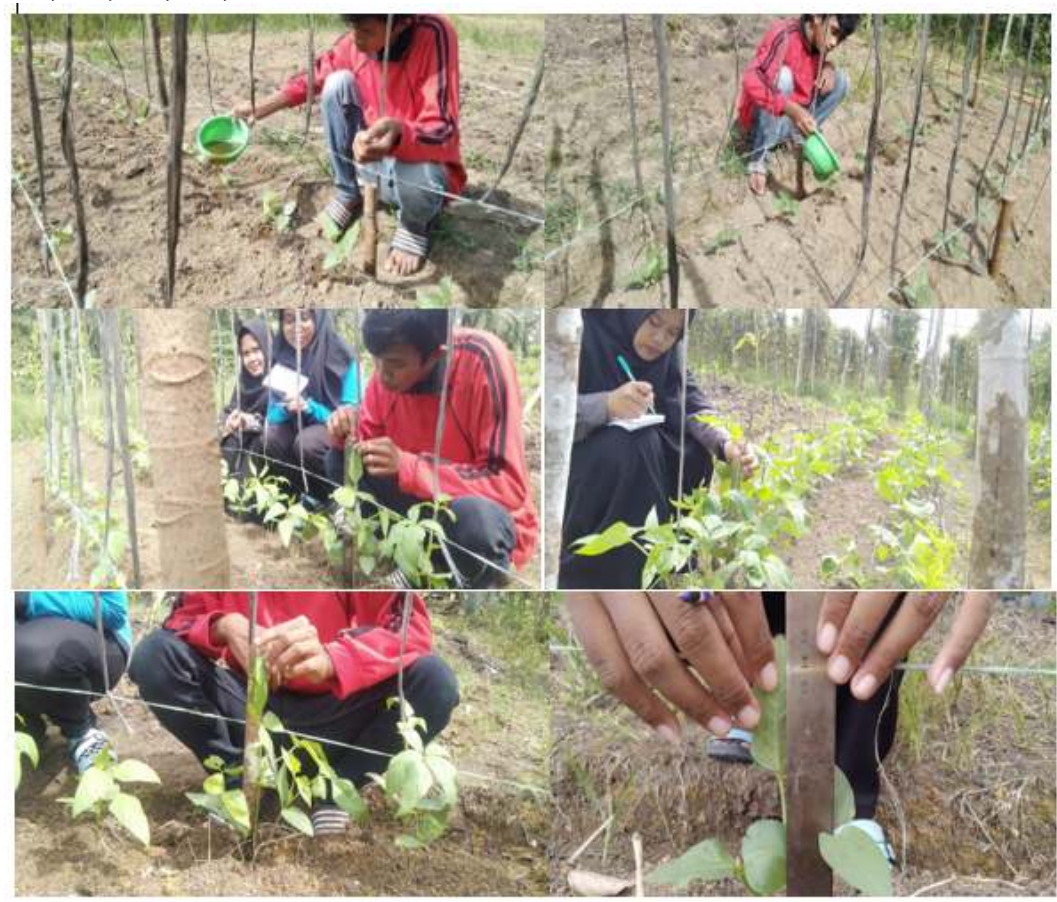

Gambar 7. Penyiraman POC, pengukuran dan perhitungan jumlah daun serta tinggi tanaman. 


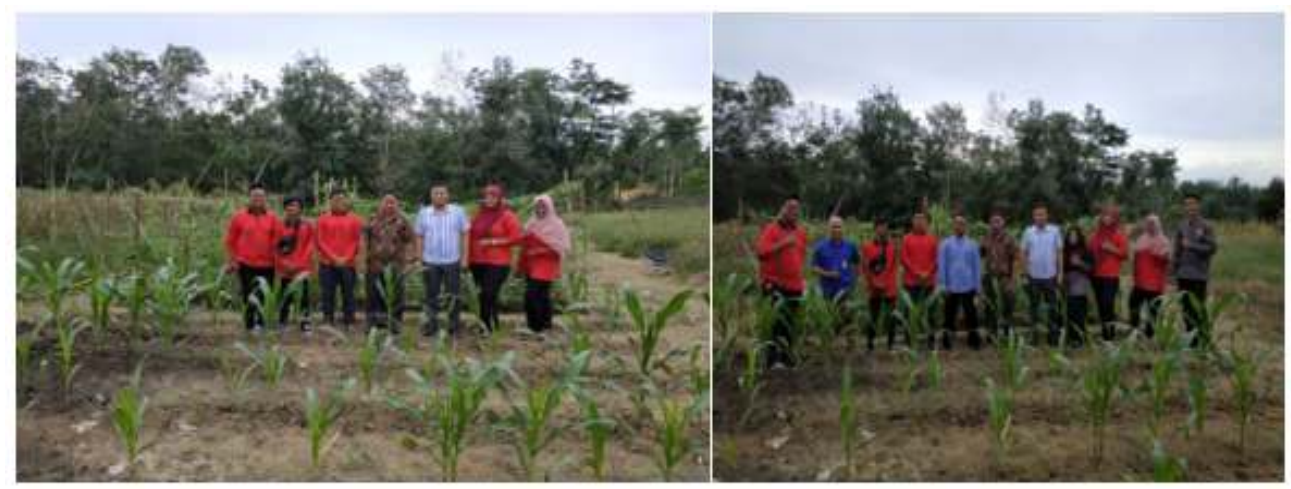

Gambar 8. Monitoring evaluation KKN MBKM di Desa Gunung Selamat

\section{HASIL DAN PEMBAHASAN}

Tabel 1. Varietas Kacang Panjang Panah Merah

\begin{tabular}{lcccccl}
\hline \multicolumn{1}{c}{ MST } & Tanaman I & $\begin{array}{c}\text { Tanaman } \\
\text { II }\end{array}$ & $\begin{array}{c}\text { Tanaman } \\
\text { III }\end{array}$ & $\begin{array}{c}\text { Tanaman } \\
\text { IV }\end{array}$ & $\begin{array}{c}\text { Tanaman } \\
\text { V }\end{array}$ & Rata-Rata \\
\hline $\begin{array}{l}\text { Minggu ke-I } \\
8 \text { Des 2020 }\end{array}$ & $15,5 \mathrm{~cm}$ & $13 \mathrm{~cm}$ & $14 \mathrm{~cm}$ & $14 \mathrm{~cm}$ & $14,5 \mathrm{~cm}$ & $\begin{array}{l}71 \mathrm{~cm} / 5= \\
14,2 \mathrm{~cm}\end{array}$ \\
\hline $\begin{array}{l}\text { Minggu ke-II } \\
15 \text { Des 2020 }\end{array}$ & $30 \mathrm{~cm}$ & $27 \mathrm{~cm}$ & $30 \mathrm{~cm}$ & $30 \mathrm{~cm}$ & $31,5 \mathrm{~cm}$ & $\begin{array}{l}148,5 \mathrm{~cm} / 5= \\
29,7 \mathrm{~cm}\end{array}$ \\
\hline $\begin{array}{l}\text { Minggu ke-III } \\
22 \text { Des 2020 }\end{array}$ & $60 \mathrm{~cm}$ & $55 \mathrm{~cm}$ & $65 \mathrm{~cm}$ & $65,5 \mathrm{~cm}$ & $77 \mathrm{~cm}$ & $\begin{array}{l}322,5 \mathrm{~cm} / 5= \\
64,5 \mathrm{~cm}\end{array}$ \\
\hline $\begin{array}{l}\text { Minggu ke-IV } \\
29 \text { Des 2020 }\end{array}$ & $125 \mathrm{~cm}$ & $100 \mathrm{~cm}$ & $130 \mathrm{~cm}$ & $145 \mathrm{~cm}$ & $145 \mathrm{~cm}$ & $\begin{array}{l}645 \mathrm{~cm} / 5= \\
129 \mathrm{~cm}\end{array}$ \\
\hline $\begin{array}{l}\text { Minggu ke-V } \\
5 \text { Jan 2021 }\end{array}$ & $145 \mathrm{~cm}$ & $130 \mathrm{~cm}$ & $155 \mathrm{~cm}$ & $160 \mathrm{~cm}$ & $168 \mathrm{~cm}$ & $\begin{array}{l}758 \mathrm{~cm} / 5= \\
151,6 \mathrm{~cm}\end{array}$ \\
\hline
\end{tabular}

Berdasarkan tabel 1 dengan varietas kacang panjang panah merah diatas dapat dilihat bahwa tanaman kacang panjang dengan pemberian perlakuan pestisida organik tingkat pertumbuhannya pada minggu pertama hingga minggu kelima memang mengalami peningkatan pertumbuhan yang signifikan sehingga dapat kita lihat pada hasil tabel diatas bahwa pemberian pestisida organik serta POC dapat meningkatkan hasil pertumbuhan pada tanaman kacang panjang.

Tabel 2. Varietas Kacang Panjang Djimat

\begin{tabular}{lcccccl}
\hline \multicolumn{1}{c}{ MST } & Tanaman I & $\begin{array}{c}\text { Tanaman } \\
\text { II }\end{array}$ & $\begin{array}{c}\text { Tanaman } \\
\text { III }\end{array}$ & $\begin{array}{c}\text { Tanaman } \\
\text { IV }\end{array}$ & $\begin{array}{c}\text { Tanaman } \\
\text { V }\end{array}$ & Rata-Rata \\
\hline $\begin{array}{l}\text { Minggu ke-I } \\
8 \text { Des 2020 }\end{array}$ & $18 \mathrm{~cm}$ & $16 \mathrm{~cm}$ & $15 \mathrm{~cm}$ & $15 \mathrm{~cm}$ & $15,8 \mathrm{~cm}$ & $\begin{array}{l}79,8 \mathrm{~cm} / 5= \\
16 \mathrm{~cm}\end{array}$ \\
\hline $\begin{array}{l}\text { Minggu ke-II } \\
15 \text { Des 2020 }\end{array}$ & $32,5 \mathrm{~cm}$ & $32,5 \mathrm{~cm}$ & $32 \mathrm{~cm}$ & $29 \mathrm{~cm}$ & $33 \mathrm{~cm}$ & $\begin{array}{l}159 \mathrm{~cm} / 5= \\
31,8 \mathrm{~cm}\end{array}$ \\
\hline $\begin{array}{l}\text { Minggu ke-III } \\
\text { 22 Des 2020 }\end{array}$ & $60 \mathrm{~cm}$ & $55 \mathrm{~cm}$ & $65 \mathrm{~cm}$ & $65,5 \mathrm{~cm}$ & $77 \mathrm{~cm}$ & $\begin{array}{l}322,5 \mathrm{~cm} / 5= \\
64,5 \mathrm{~cm}\end{array}$ \\
\hline $\begin{array}{l}\text { Minggu ke-IV } \\
\text { 29 Des 2020 }\end{array}$ & $135 \mathrm{~cm}$ & $125 \mathrm{~cm}$ & $135 \mathrm{~cm}$ & $150 \mathrm{~cm}$ & $155 \mathrm{~cm}$ & $\begin{array}{l}700 \mathrm{~cm} / 5= \\
140 \mathrm{~cm}\end{array}$ \\
\hline $\begin{array}{l}\text { Minggu ke-V } \\
\text { 5 Jan 2021 }\end{array}$ & $160 \mathrm{~cm}$ & $132 \mathrm{~cm}$ & $157 \mathrm{~cm}$ & $160 \mathrm{~cm}$ & $168 \mathrm{~cm}$ & $\begin{array}{l}777 \mathrm{~cm} / 5= \\
155,4 \mathrm{~cm}\end{array}$ \\
\hline
\end{tabular}


Berdasarkan tabel 2 varietas kacang panjang djimat diatas dapat dilihat bahwa tanaman kacang panjang dengan pemberian perlakuan pestisida kimia mengalami tingkat pertumbuhannya pada minggu pertama hingga minggu kelima memang mengalami peningkatan pertumbuhan yang signifikan dikarenakan penggunaan pestisida kimia dapat lebih mempercepat proses pertumbuhan pada setiap tanaman yang relatif cepat dibandingkan dengan hasil tabel yang ada pada tabel 1 dengan tanaman kacang panjang pada pemberian pestisida organik.

Tabel 3. Jumlah Daun Kacang Panjang Varietas Panah Merah

\begin{tabular}{llllll}
\hline $\begin{array}{c}\text { MST } \\
\text { (Minggu Setelah Tanam) }\end{array}$ & $\begin{array}{c}\text { Tanaman } \\
\text { I }\end{array}$ & $\begin{array}{c}\text { Tanaman } \\
\text { II }\end{array}$ & $\begin{array}{c}\text { Tanaman } \\
\text { III }\end{array}$ & $\begin{array}{c}\text { Tanaman } \\
\text { IV }\end{array}$ & $\begin{array}{c}\text { Tanaman } \\
\text { V }\end{array}$ \\
\hline Minggu ke-I, 8 Des 2020 & 2 helai & 2 helai & 2 helai & 2 helai & 2 helai \\
\hline Minggu ke-II, 15 Des 2020 & 5 helai & 6 helai & 6 helai & 6 helai & 6 helai \\
\hline Minggu ke-III, 22 Des 2020 & 13 helai & 13 helai & 17 helai & 17 helai & 15 helai \\
\hline Minggu ke-IV, 29 Des 2020 & 30 helai & 35 helai & 30 helai & 35 helai & 35 helai \\
\hline Minggu ke-V, 5 Jan 2021 & 60 helai & 60 helai & 50 helai & 55 helai & 55 helai \\
\hline
\end{tabular}

Tabel 4. Jumlah Daun Varietas Kacang Panjang Djimat

\begin{tabular}{llllll}
\hline \multicolumn{1}{c}{ MST } & Tanaman I & Tanaman II & Tanaman III & Tanaman IV & Tanaman V \\
\hline $\begin{array}{l}\text { Minggu ke-I } \\
8 \text { Des 2020 }\end{array}$ & 2 helai & 2 helai & 2 helai & 2 helai & 3 helai \\
\hline $\begin{array}{l}\text { Minggu ke-II } \\
\text { 15 Des 2020 }\end{array}$ & 6 helai & 6 helai & 7 helai & 7 helai & 6 helai \\
\hline $\begin{array}{l}\text { Minggu ke-III } \\
\text { 22 Des 2020 }\end{array}$ & 14 helai & 14 helai & 17 helai & 17 helai & 16 helai \\
\hline $\begin{array}{l}\text { Minggu ke-IV } \\
\text { 29 Des 2020 }\end{array}$ & 35 helai & 35 helai & 38 helai & 40 helai & 40 helai \\
\hline $\begin{array}{l}\text { Minggu ke-V } \\
\text { 5 Jan 2021 }\end{array}$ & 65 helai & 60 helai & 65 helai & 65 helai & 65 helai \\
\hline
\end{tabular}

Berdasarkan data tabel 3 dan tabel 4 dapat disimpulkan bahwa dari hasil tingkat pertumbuhan tanaman kacang panjang walaupun berbeda varietas tanaman tidak mempengaruhi, tapi berpengaruh pada tingkat hamanya. Bahwasannya hama yang menyerang tanaman kacang panjang yaitu belalang (Oxya sp., Fam. Acrididae), wereng hijau (Empoasca spp., Fam. Cicadellidae), ulat daun (Fam. Pyralidae), penggerek polong (Fam. Pyralidae), kutu aphis (Aphis craccivora, Fam. Aphididae), kepik hijau (Nezara viridula, Fam. Pentatomidae), kutu kebul (Bemisia tabaci, Fam. Hemiptera), dan Ulat Grayak (S. litura).

\section{Hasil Pengamatan Kacang Panjang dengan Varietas Panah Merah yang Diberikan Perlakuan Pestisida Organik}

Pengamatan tanaman kacang panjang dengan pemberian pestisida organik dalam penanggulangan hama dan penyakit. Dari hasil penelitian atau pengamatan yang di lakukan dari 15 - 35 HST, ternyata banyak hama yang menyerang pada tanaman kacang panjang, dari sekian banyak hama yang menyerang hama ulat grayak (S. litura) yang paling dominan yang merusak tanaman kacang panjang. Serta tanaman kacang panjang tersebut mengalami akar dan batang membusuk yang di sebabkan oleh bakteri Ralstonia solanacearum SmithYabuuchi.

Dapat disimpulkan bahwasannya ternyata penggunakan pestisida organik kurang efektif dalam penanggulangan hama dan penyakit pada tanaman kacang panjang (Vigna sinensis L.). Gejala tanaman yang terserang ulat berupa daun berlubang, pada serangan berat hanya tersisa tulang daunnya saja. Dalam varietas kacang panjang Panah Merah berdasarkan perlakuan 
menunjukkan pola fluktuasi populasinya sama yaitu meningkat hingga $35 \mathrm{HST}$, selanjutnya mengalami penurunan.

Hal ini diduga ulat memiliki kecenderungan menyerang tanaman fase vegetatif hingga fase generatif, akan tetapi pada akhir fase generatif populasinya mulai menurun kembali. Bahkan (Shahabuddin \& Mahfudz, 2010) penelitiannya tentang kepadatan populasi suatu hama dan persentase serangan ulat grayak (S. litura) juga menunjukkan peningkatan populasi pada umur tertentu, selanjutnya menurun menjelang panen.

\section{Hasil Pengamatan Kacang Panjang dengan Varietas Djimat yang Diberikan Perlakuan Pestisida Organik}

Dari hasil penelitian atau pengamatan yang di lakukan dari 15 - 35 HST, ternyata hama yang menyerang pada tanaman kacang panjang dapat dikendalikan, hal ini disebabkan karena tanaman kacang panjang tersebut diberi atau disemprotkan pestisida kimia. Namun selain itu, faktor cuaca diduga juga mempengaruhi jumlah populasi (individu) perkembangan hama saat itu. Penelitian (Indiati, 2007), faktor hama berpengaruh terhadap pertumbuhan dan hasil tanaman. (Aprilianto \& Setiawan, 2014) menekankan lagi bahwa hama merupakan salah satu faktor yang menyebabkan kehilangan hasil pada suatu pertanaman. Lebih lanjut (Herlinda, 2004), fluktuasi populasi hama di lapangan selain dipengaruhi umur tanaman, juga dipengaruhi faktor fisik, seperti curah hujan.

\section{Gejala Penyakit pada Tanaman Kacang Panjang}

Ketika tanaman kacang panjang berumur 15-35 HST hama yang menyerang tanaman kacang panjang yaitu grayak (S. litura), gejala yang ditimbulkan oleh ulat grayak yaitu menibulkan, virus bean common mosaic virus (BCMV) pada tanaman kacang panjang adalah dengan adanya gejala bercak kekuning-kuningan dan gejala melepuh sehingga menyebabkan kerusakan dan kegagalan panen.

Dalam pengaplikasian Pupuk Organik Cair (POC), Pestisida Organik serta Pestisida Kimia pada tanaman kacang panjang dengan 2 varietas yang berbeda dapat dilihat dari segi pertumbuhan tinggi tanaman dan jumlah daun mengalami perubahan yang sangat signifikan dari 15-35 HST dikarenakan hama yang menyerang pada tanaman kacang panjang dengan perlakuan pestisida organik lebih meningkat ditambah lagi gejala yang ditimbulkan oleh ulat grayak yaitu menibulkan, virus bean common mosaic virus (BCMV) pada tanaman kacang panjang adalah adanya bercak kekuning-kuningan dan gejala melepuh hasil ini jauh berbeda dibandingkan dengan perlakuan atau pemberian pestisida kimia, sehingga menyebabkan kerusakan serta kegagalan panen dan hasil yang diharapkan kurang memenuhi keinginan demi mengurangi penggunaan pestisida kimia namun, jika dibarengkan dengan penggunaan pestisida kimia juga akan mendapatkan hasil yang diinginkan.

\section{KESIMPULAN DAN SARAN \\ Kesimpulan}

Berdasarkan penelitian yang sudah dilakukan selama dilapangan dapat disimpulkan bahwa Perlakuan pemberian pupuk organik cair dan pestisida organik terhadap pemberian pestisida kimia pada tanaman berpengaruh nyata pada tanaman kacang panjang, bahwasannya tanaman kacang panjang yang diberikan perlakuan pemberian pestisida kimia menujukkan hasil pertumbuhan yang signifikan baik dibandingkan dengan pemberian pestisida organik. Pada umur 35 HST tanaman kacang panjang rentan dengan terserangnya hama dan penyakit sehingga tanaman kacang panjang mengalami kerusakan, jadi dapat disimpulkan bahwasannya tanaman kacang panjang akan sulit mengalami pertumbuhan yang baik jika tidak dibantu oleh pestisida kimia dalam menangani hama dan penyakitnya. Selain itu, pemberian pupuk organik cair (POC) urin kambing tidak berpengaruh terhadap semua parameter pengamatan. Tidak adanya interaksi 
atau respon dari pemberian pupuk organik cair (POC) urin kambing dan pestisida organik pada semua parameter pengamatan.

\section{Saran}

Rasanya perlu untuk dilakukan tindak lanjut dalam menggunakaan pestisida organik agar menghasilkan tanaman yang diinginkan. Untuk memperbaiki sifat biologi, fisik dan kimia tanah, perlu digalakkan dalam pemakaian pupuk organik secara berkesinambungan agar mengurangi penggunaan pupuk kimia. Walhasil alangkah baiknya bila dilakukan penelitian lebih lanjut dalam pembuatan dan pengaplikasian pestisida organik untuk mendapatkan pengaruh yang signifikan terhadap pertumbuhan dan hasil tanaman kacang panjang dalam mengurangi penggunaan pestisida kimia sehingga dapat mengurangi pencemaran tanah, air dan lingkungan.

\section{DAFTAR PUSTAKA}

Aprilianto, E., \& Setiawan, B. H. (2014). Perkembangan Hama dan Musuh Alami pada Tumpangsari Tanaman Kacang Panjang dan Pakcoy. Igarss 2014, XVI(1), 1-5.

Arinong, R. A. (2013). Aplikasi Pupuk Organik dan Umur Pemangkasan terhadap Pertumbuhan dan Produksi Tanaman Kacang Panjang (Vigna sinensis L.).

BPS. (2015). Produksi Sayuran di Indonesia. http://www.bps.go.id/tab_sub/view. php? $=1 \&$ daftar $=1 \&$ id_subyek=55\&notab=20. Diakses tanggal 29 April 2021

Djojosumarto, P. (2008). Teknik Aplikasi Pestisida Pertanian. Kanisius.

Dudung. (2013). Pupuk Kandang. PT. Citra Aji Parama.

Haryanto, E., T. Suhartini, \& E. Rahayu. (2007). Budidaya Kacang Panjang. Penebar Swadaya. hal 69.

Herlinda, S. (2004). Jenis tumbuhan inang, serta populasi dan kerusakan oleh pengorok daun, Liriomyza huidobrensis (Blanchard) pada tanaman kubis (Brassica oleracea L.). Jurnal Tanaman Tropika, 7(1), 59-68.

Hodiyah, I., \& Hartini, E. (2015). Efikasi beberapa bahan pestisida nabati dalam mengendalikan hama tanaman cabai (Capsicum annum L.). Jurnal Agroekoteknologi, 6(2), 1-14. https://doi.org/10.33512/j.agrtek.v6i2.202

Indiati, S. W. (2007). Pengendalian Hama Penggerek Polong pada Tanaman Kacang Hijau. Pengendalian Hama Penggerek Polong Pada Tanaman Kacang Hijau, 11(2), 138-147. SW Indiati - Jurnal Agrin, 2007 - jurnal.faperta.unsoed.ac.id

Julaily, N., Mukarlina, \& Septyawati T,R. (2013). Pengendalian Hama pada Tanaman Sawi (Brassica juncea L.) Menggunakan Ekstrak Daun Pepaya (Carica pepaya L.). Jurnal Protobiont, 2(3):171-175.

Kurdianingsih, S. A. R. A. R. (2017). Efektivitas pupuk kalium organik cair dan tahapan pemupukan kalium terhadap pertumbuhan, produksi, dan daya simpan kacang panjang (Vigna sesquipedalis (L.) Fruhw.) KULTIVAR KP-1 The Efficacy of Liquid Organic Potassium Fertilizer and Steps of Fertilizer A. Jurnal Agronida, 1(2), 92-105.

Kurdianingsih, S., A. Rahayu, \& Setyono. (2015). Efek Pupuk Kalium Organik Cair dan Tahapan Pemupukan Kalium Terhadap Pertumbuhan, Produksi, dan Daya Simpan Kacang Panjang (Vigna sesquipedalis L. Fruhw). [jurnal]. Fakultas Pertanian. Universitas Djuanda Bogor.

Kuswanto, (2009). Keragaman Genetik Populasi Bulk F2, F3 Dan F4 Kacang Panjang (Vigna sesquipedalis (L) Fruwirth) Hasil Persilangan PS x MLG15151, Agrivita 28 (2) : 109-114 Juni 2006 ISSN : $0126-0537$

Kuswanto, B. W., Soetopo, L., \& Afandhi, A. (2009). Uji Daya Hasil Galur Harapan Kacang Panjang Toleran Hama Aphid Dan Berdaya Hasil Tinggi. Agrivita 31 (1) : 31-40

Rahmawati, R. (2012). Cepat \& Tepat Berantas Hama \& Penyakit Tanaman. Pustaka Baru Press. 
Shahabuddin, \& Mahfudz. (2010). Pengaruh Aplikasi Berbagai Jenis Insektisida Terhadap Ulat Bawang (Spodoptera Exigua Hubn) dan Produksi Bawang Merah Varietas Bima dan Tinombo. Fakultas Pertanian. Universitas Tadulako Sulawesi Tengah. Jurnal Agroland 17 (2) : 115-122.

Simanungkir, S. RH, Dahlan, Z. (2006). Pupuk Organik dan Pupuk Hayati. Balai Besar Litbang Sumber Daya Lahan Pertanian. Badan Penelitian dan Pengembangan Pertanian.

Sundari, E. (2012). Pembuatan Pupuk Organik Cair Menggunakan Bioaktivator Biosca dan EM4. Kanisius.

Zaevie, B., Napitupulu, M., \& Astuti, P. (2014). Respon Tanaman Kacang Panjang (Vigna sinensis L.) Terhadap Pemberian Pupuk NPK Pelangi dan Pupuk Organik Cair Nasa. Jurnal AGRIFOR, XIII(1), 19-32. 